\title{
EAR, NOSE AND THROAT TUMOURS- A THREE-YEAR EXPERIENCE
}

\author{
Batchu Krishna Santosh ${ }^{1}$, Amjad Khan², Pinnamaneni Madhava Priya ${ }^{3}$
}

${ }_{1}^{1}$ Assistant Professor, Department of ENT, GSL Medical College and General Hospital, Rajahmundry, Andhra Pradesh, India. 2Postgraduate Student, Department of ENT, GSL Medical College and General Hospital, Rajahmundry, Andhra Pradesh, India. 3Postgraduate Student, Department of ENT, GSL Medical College and General Hospital, Rajahmundry, Andhra Pradesh, India.

\section{ABSTRACT}

\section{BACKGROUND}

Otorhinolaryngology (ENT) tumours constitute an important public health problem and are common in both urban and rural communities, although very few studies have been conducted to know the prevalence of the tumours.

This study aims to determine the different types of ENT tumours in the backward rural region to get an overall understanding of tumours in that region, which will help in future to formulate concrete measures to manage such patients and also to create awareness among population about these tumours, methods of prevention, and management.

\section{MATERIALS AND METHODS}

It is a descriptive study conducted for a period of 3 years at GSL Medical College and General Hospital, Rajahmundry from 2014 to 2017. Patients with ENT tumours who presented to OP and IP department in GSL Hospital were considered and all suspected malignant tumours were screened initially. Later therapeutic surgical removal of the tumours was done, and the materials were sent to pathology department for final diagnosis.

\section{RESULTS}

A total of 140 cases were recorded during three years. Males constituted $55.8 \%$ and females constituted $44.2 \%$. The mean age of the patients was $53 \pm 14$ years with a minimum age of 18 years and maximum age of 80 years. Majority of tumour occurrence was in the age group of 51 to 70 years. Among malignant tumours, squamous cell carcinoma was most common followed by premalignant leukoplakia. Among benign tumours, angiofibroma, spindle cell tumours and papillomas were more common.

\section{CONCLUSION}

The present study identified the distribution of various tumours in the region of Rajahmundry. The presence of more number of malignant tumours reflects a poor early diagnosis and screening technique. There is a need for screening of persons of both genders, above 50 years of age, for ENT tumours which will aid in early management. Primary prevention, health education, and awareness regarding the ENT tumours at the village level should be given priority.

\section{KEY WORDS}

Ear, Nose and Throat (ENT) Tumours, Rajahmundry, Andhra Pradesh.

HOW TO CITE THIS ARTICLE: Santosh BK, Khan A, Priya PM. Ear, nose and throat tumours- a three-year experience. J. Evolution Med. Dent. Sci. 2018;7(38):4227-4229, DOI: 10.14260/jemds/2018/943

\section{BACKGROUND}

Ears, nose and throat are important sensory organs which play a great role in a day-to-day functioning and are adjacent to one another anatomically. Dysfunction of the ears, nose or throat not only disrupts daily life, but in some cases obstruction to nose and throat could portend a threat to life Due to their proximity to the eyes and brain, early diagnosis of ENT tumours and management is important. ${ }^{1}$

Head and Neck Tumours (HNT) consist of a diverse group of tumours that ranges from cutaneous lip, salivary glands, sinuses, oral cavity, pharynx and larynges. ${ }^{2}$ Head and neck tumours are the sixth most prevalent neoplasms in the world

'Financial or Other Competing Interest': None.

Submission 10-08-2018, Peer Review 04-09-2018,

Acceptance 11-09-2018, Published 17-09-2018.

Corresponding Author

Dr. Batchu Krishna Santosh

Assistant Professor

Department of ENT,

GSL Medical College and General Hospital,

Rajahmundry, Andhra Pradesh, India.

E-mail: sankris81@yahoo.com

DOI: $10.14260 /$ jemds $/ 2018 / 943$ with approximately 9 lakhs cases diagnosed worldwide per year. The prevalence of ENT disorders in rural area was $4.31 \%$ and the ear is the commonest part affected. ${ }^{3}$ In India, Head and Neck Cancers (HNCA) account for 30 - 40\% cancers at all sites. The prevalence is found to be significantly high at $54.48 \%$, affecting males more than females in the age group of 40 - 69 years. ${ }^{4}$

Otorhinolaryngology (ENT) tumours are common in both urban and rural communities with predominance in rural community. ${ }^{5}$ There are just a few studies in literature describing the prevalence of ENT tumours. ${ }^{6}$ There is not much data available on the prevalence of ENT tumours in rural community in India. A proper understanding of the magnitude of ENT tumours and their occurrence in the rural population is important to enable formulation of health care service aimed at early detection and treatment of morbidity. This study aims to determine the different types of ENT tumours in the rural backward region to get an overall understanding of tumours in that region, which will help us in future to formulate a concrete measure to manage such patients in the future and also to create awareness among population about these tumours and method of prevention and management. 


\section{MATERIALS AND METHODS}

A descriptive study was conducted in GSL Medical College and General Hospital, Rajahmundry, Andhra Pradesh for a period of 3 years from 2014 to 2017. Patients with ENT tumours who presented to OP and IP department in the GSL Hospital were considered. All suspected malignant tumours were screened initially and later therapeutic surgical removal of the tumours were done and the materials were sent to pathology for final diagnosis. Patients with inadequate specimen and those patients who did not give consent were not included in the study. The data was tabulated in Microsoft Excel Sheet and later analysed. Data is expressed in terms of means, percentages and proportions.

\section{RESULTS}

A total of 140 cases were recorded during three years. Males constituted $56 \%$ and females constituted $44 \%$ (Fig. 1). The mean age of the patients was $53 \pm 14$ years with a minimum age of 18 years and maximum age of 80 years. Majority of tumour occurrence was in the age group of 51 to 70 years (Table 1).

Most of the carcinomas were observed between the age groups of 51 and 70 years. Overall prevalence of different tumours in broad classification is given under Table No. 2 .

In the present observational study, among malignant tumours squamous cell carcinomas were recorded higher in number, whereas premalignant leucoplakia was the common presentation.

The mean age of presentation of different tumours were given under Table 3. Leiomyoma, squamous papilloma, spindle cell tumour, squamous cell carcinoma, invasive and adenocystic carcinoma was above 60 years of age, whereas hyperplastic squamous epithelium, erythroplakia, poorly differentiated squamous cell carcinoma, moderately differentiated squamous cell carcinoma, stratified squamous epithelium, leukoplakia, squamous cell carcinoma with welldifferentiated, keratinising squamous cell carcinoma, moderately differentiated squamous cell carcinoma and dysplastic squamous epithelium was above 50 years of age.

The most common sites of tumours are hard palate, tongue, vocal cords, post cricoid regions, buccal mucosa, supraglottis, pyriform fossa and posterior pharyngeal wall and the distribution of other regions were mentioned in Table 4.

Almost all the tumours were equally distributed between Males and Females. Moderately differentiated squamous cell carcinoma and well-differentiated squamous cell carcinoma were proportionally high in males when compared to females, but there was no statistical significant difference.

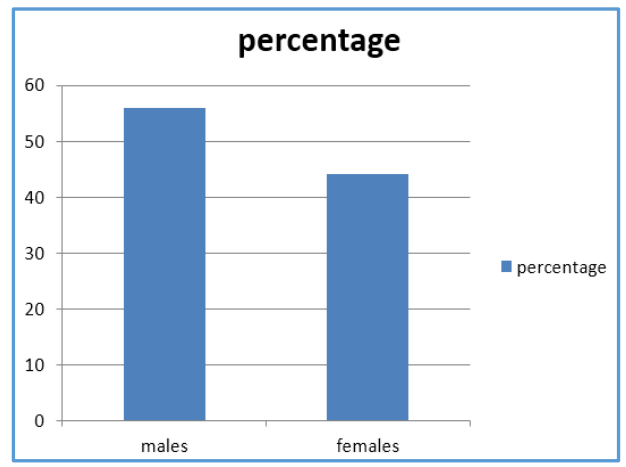

Figure 1. Gender Distribution

\begin{tabular}{|c|c|c|}
\hline Age Distribution & Number & Percentage \\
\hline 10 to 20 & 3 & 2.14 \\
\hline 21 to 30 & 11 & 7.86 \\
\hline 31 to 40 & 16 & 11.43 \\
\hline 41 to 50 & 26 & 18.57 \\
\hline 51 to 60 & 43 & 30.71 \\
\hline 61 to 70 & 32 & 22.86 \\
\hline 71 to 80 & 9 & 6.43 \\
\hline \multicolumn{2}{|c|}{ Table 1. Age Distribution of Study Subjects } \\
\hline
\end{tabular}

\begin{tabular}{|c|c|c|}
\hline & Number & Percentage \\
\hline \multicolumn{3}{|l|}{ Malignant } \\
\hline \multicolumn{3}{|l|}{ Squamous cell carcinoma } \\
\hline $\begin{array}{l}\text { a. Well differentiated squamous } \\
\text { cell carcinoma }\end{array}$ & 34 & 24.29 \\
\hline $\begin{array}{l}\text { b. Poorly differentiated squamous } \\
\text { cell carcinoma }\end{array}$ & 2 & 1.43 \\
\hline $\begin{array}{l}\text { c. Moderately differentiated } \\
\text { squamous cell carcinoma }\end{array}$ & 71 & 50.71 \\
\hline Adenocarcinoma & 2 & 1.43 \\
\hline Invasive carcinoma & 2 & 1.43 \\
\hline Olfactory Neuroblastoma & 2 & 1.43 \\
\hline Adenocystic carcinoma & 1 & 0.71 \\
\hline Verrucous carcinoma & 1 & 0.71 \\
\hline $\begin{array}{l}\text { Keratinising squamous cell } \\
\text { carcinoma }\end{array}$ & 1 & 0.71 \\
\hline \multicolumn{3}{|l|}{ Premalignant } \\
\hline Leukoplakia & 9 & 6.43 \\
\hline Dysplasia & 2 & 1.43 \\
\hline Erythroplakia & 1 & 0.71 \\
\hline Hyperplastic epithelium & 1 & 0.71 \\
\hline \multicolumn{3}{|l|}{ Benign } \\
\hline Angiofibroma & 2 & 1.43 \\
\hline Spindle cell tumours & 2 & 1.43 \\
\hline Papilloma & 2 & 1.43 \\
\hline Cavernous haemangioma & 1 & 0.71 \\
\hline Capillary haemangioma & 1 & 0.71 \\
\hline Haemangioendothelioma & 1 & 0.71 \\
\hline Pleomorphic adenoma & 1 & 0.71 \\
\hline Leiomyoma & 1 & 0.71 \\
\hline
\end{tabular}

Table 2. Distribution of Tumours (Broad Classification)

\begin{tabular}{|c|c|}
\hline Types of Tumours & $\begin{array}{c}\text { Mean } \pm \text { SD } \\
\text { (Years) }\end{array}$ \\
\hline Leiomyoma & 75 \\
\hline Squamous papilloma & $68 \pm 8$ \\
\hline Spindle cell tumour & 66 \\
\hline Invasive squamous cell carcinoma & $64 \pm 2$ \\
\hline Adenocystic carcinoma & 63 \\
\hline Hyperplastic squamous epithelium & 60 \\
\hline Erythroplakia & 58 \\
\hline Poorly differentiated squamous cell carcinoma & $57 \pm 5$ \\
\hline Squamous cell carcinoma, moderately & $56 \pm 13$ \\
\hline differentiated & $55 \pm 10$ \\
\hline Stratified squamous epithelium & $55 \pm 10$ \\
\hline Leukoplakia & $54 \pm 13$ \\
\hline Squamous cell carcinoma, well-differentiated & 53 \\
\hline Keratinising squamous cell carcinoma, \\
moderately differentiated & $52 \pm 9$ \\
\hline Dysplastic squamous epithelium & 50 \\
\hline Benign epithelial cyst & $49 \pm 6$ \\
\hline Adenocarcinoma of salivary gland & $48 \pm 14$ \\
\hline Squamous cell carcinoma, poorly differentiated & 45 \\
\hline Capillary haemangioma & $41 \pm 19$ \\
\hline Angiofibroma & 40 \\
\hline Haemangioma &
\end{tabular}




\begin{tabular}{|c|c|}
\hline Verrucous carcinoma & 40 \\
\hline Moderate dysplasia of squamous epithelium & 38 \\
\hline Olfactory neuroblastoma & $32 \pm 4$ \\
\hline Haemangioendothelioma & 30 \\
\hline Sarcomatoid tumour & 28 \\
\hline Pleomorphic adenoma & 27 \\
\hline Benign spindle cell tumour & 25 \\
\hline Cavernous haemangioma & 20 \\
\hline Squamous cell carcinoma, undifferentiated & 18 \\
\hline Table 3. Mean Age of Presentation of different Tumours \\
\hline
\end{tabular}

\begin{tabular}{|c|c|c|}
\hline Area of Involvement & Number & Percentage \\
\hline Hard palate & 27 & 19.29 \\
\hline Tongue & 18 & 12.86 \\
\hline Vocal cords & 13 & 9.29 \\
\hline Post cricoid & 11 & 7.86 \\
\hline Buccal mucosa & 9 & 6.43 \\
\hline Supraglottis & 8 & 5.71 \\
\hline Pyriform fossa & 7 & 5.00 \\
\hline Posterior pharyngeal wall & 6 & 4.29 \\
\hline Floor of mouth & 5 & 3.57 \\
\hline Nasal cavity & 5 & 3.57 \\
\hline Arytenoids & 4 & 2.86 \\
\hline Epiglottis & 4 & 2.86 \\
\hline Nasopharynx & 4 & 2.86 \\
\hline Tonsil & 3 & 2.14 \\
\hline Maxillary sinus & 3 & 2.14 \\
\hline Retromolar trigone & 2 & 1.43 \\
\hline Parotid & 2 & 1.43 \\
\hline Oropharynx & 2 & 1.43 \\
\hline Soft palate & 2 & 1.43 \\
\hline Base of tongue & 1 & 0.71 \\
\hline Subglottis & 1 & 0.71 \\
\hline Alveolus & 1 & 0.71 \\
\hline Ear & 1 & 0.71 \\
\hline Vallecula & 1 & 0.71 \\
\hline Total & $\mathbf{1 4 0}$ & $\mathbf{1 0 0}$ \\
\hline Table 4. Areas of Involvement \\
\hline & &
\end{tabular}

\section{DISCUSSION}

Otorhinolaryngology disorders still represent an important cause of morbidity and mortality and is one of the major public health problems in developing countries. Data regarding ENT tumours is lacking in Andhra Pradesh. The present study is an attempt for the first time to report prevalence of ENT tumours in the Rajahmundry district of Andhra Pradesh. The study was conducted for a period of 3 years to study different types of ENT tumours. A total of 140 tumours were studied during the study period. In the present study male predominance was seen and majority of tumour occurrence was in the age group of 51 to 70 years. In a study conducted by Taiwo 0 et al, out of 211 cases 131 (62.1\%) were males with a mean age of $32.8 \pm 22.4$ years. ${ }^{1}$ Among malignant tumours squamous cell carcinomas were recorded higher in number, whereas premalignant leucoplakia were the common presentation the reason being high number of malignant cases. As the study is conducted in a tertiary care hospital, patients with complications and chronic symptoms will seek the health care facilities at large. Most head and neck cancers are of epithelial origin. In the literature it is reported that $75 \%-78 \%$ of head and neck carcinomas are SCC, 7,8 which is similar to our study findings. Our experience in this study is similar with the previous reports from Nepal with squamous cell carcinoma accounting for nearly $62 \%$ of head and neck carcinomas. ${ }^{9}$ The most common sites of tumours are hard palate, tongue, vocal cords, post cricoid regions, buccal mucosa, supraglottis, pyriform fossa and posterior pharyngeal wall. In a clinical study of head and neck malignancy conducted by Hamsa Shetty et al, who observed that malignancy of oropharynx was in 3 rd place followed by oesophagus and oral cavity.10 Moderately differentiated squamous cell carcinoma and well differentiated squamous cell carcinoma were proportionally high in males when compared to females. This may be due to high-risk factors like smoking and chewing tobacco in males.

\section{CONCLUSION}

The present study identified the distribution of various tumours in the region of Rajahmundry. The presence of more number of malignant tumours reflects poor early diagnosis and screening techniques. There is a need for screening of both genders, above 50 years of age, for ENT tumours which will aid in early management. Primary prevention, health education, and awareness regarding the ENT tumours at the village level should be given priority.

\section{REFERENCES}

[1] Adedeji TO, Sogebi OA, Tobih JE. Pattern of otorhinolaryngological admissions via emergency unit in a Suburban tertiary center. Int J Biomed Sci 2015;11(3):146-51.

[2] Chin D, Boyle GM, Porceddu S, et al. Head and neck cancers: past, present and future. Expert Rev Anticancer Ther 2006;6(7):1111-8.

[3] Singh A, Kumar S. A survey of ear, nose and throat disorders in rural India. Indian J Otolaryngol Head Neck Surg 2010;62(2):121-4.

[4] Bhattacharjee A, Chakraborty A, Purkaystha P. Prevalence of head and neck cancers in the north east-an institutional study. Indian J Otolaryngol Head Neck Surg 2006;58(1):15-9.

[5] Bhattia PL, Varughese R. Pattern of otorhinolaryngological diseases in Jos community. Nig Med J 1987;17:67-73.

[6] Zakzouk SM, Jamal TS, Daghistani KJ. Epidemiology of acute otitis media among Saudi children. International Journal of Pediatric Otorhinolaryngology 2002;62(3):219-22.

[7] Thapa N, Jha AK, Rijal JP, et al. Study on head and neck tumours presented in ENT OPD of Nepal Medical College teaching Hospital. Nepal Med Coll J 2003;5(2):79-81.

[8] Baskota DK, Agrawal R, Prasad R, et al. Distribution of malignancies in head and neck regions and their management. J Nep Med Assoc 2005;44:68-72.

[9] Lasrado S, Prabhu P, Kakria A, et al. Clinic pathological profile of head and neck cancers in the western development region, Nepal: a 4-year snapshot. Asian Pacifc Journal of Cancer Prevention 2012;13(12):6059-62.

[10] Shetty H, Gangadhar KS. A clinical study of head and neck malignancy in a tertiary hospital. Int J Otorhinolaryngol Head Neck Surg 2015;1(2):69-74. 